\title{
Correction: Robust metrics for assessing the performance of different verbal autopsy cause assignment methods in validation studies
}

\author{
Christopher JL Murray*, Rafael Lozano, Abraham D Flaxman, Alireza Vahdatpour and Alan D Lopez
}

\section{Correction}

After publication of this manuscript [1], it came to the attention of the authors that the manuscript contained an error in the equation and text on page 5. The corrected version is below.

Based on simplicity and the robustness to the CSMF composition of the test dataset, we propose to measure chance-corrected concordance for cause $\mathrm{j}\left(\mathrm{CCC}_{\mathrm{j}}\right)$ as:

$$
C C C_{j}=\frac{\left(\frac{T P_{j}}{T P_{j}+F N_{j}}\right)-\left(\frac{1}{N}\right)}{1-\left(\frac{1}{N}\right)}
$$

Where TP is true positives, FN is false negatives, and $\mathrm{N}$ is the number of causes, TP plus FN equals the true number of deaths from cause $\mathrm{j}$.

The Publisher and authors apologize to the readers for any inconvenience caused.

\section{Received: 10 March 2014 Accepted: 17 March 2014}

Published: 10 April 2014

\section{References}

1. Murray CJL, Lozano R, Flaxman AD, Vahdatpour A, Lopez AD: Robust metrics for assessing the performance of different verbal autopsy cause assignment methods in validation studies. Population Health Metrics 2011, $9 \cdot 28$

\section{doi:10.1186/1478-7954-12-7}

Cite this article as: Murray et al:: Correction: Robust metrics for assessing the performance of different verbal autopsy cause assignment methods in validation studies. Population Health Metrics 2014 12:7.

\footnotetext{
* Correspondence: cjlm@uw.edu

Institute for Health Metrics and Evaluation, University of Washington, 2301
}

Fifth Ave., Suite 600 Seattle, WA 98121, USA

\section{Submit your next manuscript to BioMed Central and take full advantage of:}

- Convenient online submission

- Thorough peer review

- No space constraints or color figure charges

- Immediate publication on acceptance

- Inclusion in PubMed, CAS, Scopus and Google Scholar

- Research which is freely available for redistribution 